Berkala Ilmu Perpustakaan dan Informasi, Vol. 13, No. 2, Desember 2017, Hal. 205-216 DOI: http:// 10.22146/bip.26312

ISSN 1693-7740 (Print), ISSN 2477-0361 (Online)

Tersedia online di https://jurnal.ugm.ac.id/bip

\title{
PRODUKTIFITAS PENULIS ARTIKEL MAJALAH ILMIAH PSIKOLOGI UNIVERSITAS GADJAH MADA MENGGUNAKAN DALIL LOTKA
}

\author{
Pergola Irianti ${ }^{1}$ \\ ${ }^{1}$ Pustakawan Universitas Gadjah Mada \\ e-mail: pergola_irianti@ugm.ac.id
}

Naskah diterima: 6 Juli 2017, direvisi: 18 September 2017, disetujui: 28 September 2017

\begin{abstract}
ABSTRAK
Kajian produktivitas penulis menggunakan dalil Lotka sudah pernah dilakukan pada beberapa bidang ilmu, seperti perpustakaan, fisika, kimia, sosial dan politik. Kajian porudktivitas bidang psikologi khususnya di Indonesia masih jarang dilakukan. Kajian ini bertujuan untuk (1) mengetahui produktivitas penulis artikel bidang ilmu psikologi menggunakan dalil Lotka, khususnya yang disajikan dalam Jurnal Psikologi dan Buletin Psikologi yang diterbitkan Fakultas Psikologi UGM, (2) mengetahui penulis yang produktif dalam dua publikasi tersebut dengan pendekatan bibliometri dan dianalisis secara kuantitatif menggunakan dalil Lotka. Hasil analisis menunjukkan bahwa: (1) Produktivitas penulis Jurnal Psikologi dengan melibatkan penulis pertama (straight count) hasilnya sesuai dengan dalil Lotka, karena ${ }_{\text {Dmaks }}<$ nilai titik kritis. Sebaliknya apabila penghitungan dilakukan dengan melibatkan semua penulis (complete count) hasil yang duperoleh tidak sesuai dengan dalil Lotka, karena ${ }_{\text {Dmaks }}>$ nilai titik kritis. (2) Produktivitas penulis Buletin Psikologi dengan melibatkan penulis pertama (straight count) hasilnya menunjukkan bahwa Dmaks $>$ nilai titik kritis berarti tidak sesuai dengan dalil Lotka. Demikian pula untuk produktivitas dengan melibatkan semua penulis menunjukkah hasil yang tidak sesuai dengan dalil Lotka karena ${ }_{\text {Dmaks }}>$ nilai titik kritis. (3) Hasil yang lain menunjukkan bahwa Faturochman merupakan penulis yang paling produktif pada dua majalah ilmiah tersebut.
\end{abstract}

Kata kunci: Produktivitas penulis, bibliomteri, media komunikasi ilmiah

\section{ABSTRACT}

Limited research has been found in the area of Psychology using Lotka law in Indonesia. In other fields such as physics, chemistry, library and information, social science and politics, study of authors productivity using Lotka's Law has been conducted. is. This study aims to: (1) examine the productivity of authors in the field of psychology, particularly in scientific psychology papers published by the Fakultas Psikologi UGM, using the law of Lotka; (2) understand authors who are productive in the journals and bulletion at the faculty of Psychology UGM. This study uses a bibliometric approach, analized quantitatively using Lotka's law. The results show that: (1) Authors productivity of Psychology journals by involving first writer (straight count) according to Lotka's law, that is Dmaks < critical point value. Conversely, if the calculation is conducted by involving all authors (complete count) the results obtained are not in accordance with Lotka's law, because ${ }_{\text {Dmax }}>$ critical point value. (2) Productivity of the author of the Bulletin involving the first author (straight count) shows that ${ }_{\text {Dmax }}>$ the critical point value is not accordance with Lotka's law. Similarly, productivity by involving all authors is also inconsistent with Lotka's law because ${ }_{\text {Dmax }}>$ the critical point. Other results indicate that Faturochman was the most prolific writer of the two scientific magazines.

Keywords: author productivity, bibliometric, scientific communication media 


\section{A. PENDAHULUAN}

Setiap lembaga pendidikan tinggi atau perguruan tinggi mempunyai kewajiban melaksanakan Tri Dharma Perguruan Tinggi yang meliputi pendidikan, penelitian, dan pengabdian kepada masyarakat. Penelitian bermanfaat untuk pengembangan ilmu dan pengetahuan bidang ilmu yang diselenggarakan oleh lembaga induknya. Seperti dikemukakan oleh Wahyudi, dkk. (2015) penelitian merupakan salah satu cara untuk menjawab berbagai permasalahan yang ada dan memperluas cakupan ilmu pengetahuan. Optimalisasi pemanfaatan hasil-hasil penelitian dapat dilakukan dengan mempublikasikannya kepada khalayak. Dalam lingkup perguruan tinggi, publikasi hasil penelitian dilakukan melalui penerbitan majalah ilmiah, jurnal dan prosiding. Majalah ilmiah merupakan media komunikasi ilmiah untuk menyebarkan hasilhasil penelitian dalam lingkup perguruan tinggi, dan eksistensinya menjadi salah satu unsur penilaian dalam akreditasi perguruan tinggi. Menurut Purnomowati (2001) produktivitas majalah ilmiah menjadi indikator kemajuan ilmu pengetahuan dan teknologi sebuah negara.

Produktivitas sebuah majalah ilmiah ditentukan oleh dukungan penulis dengan menyumbangkan karya tulisnya. Dukungan dan eksistensi penulis dalam majalah ilmiah bidang ilmu tertentu menunjukkan produktivitasnya pada majalah ilmiah tersebut. Menurut Tsay (2004) produktivitas penulis menunjukkan banyaknya karya tulis yang dihasilkan dalam kurun waktu tertentu.

Berkaitan dengan produktivitas penulis, dikemukakan oleh Lotka bahwa ada hubungan terbalik antara jumlah artikel yang ditulis dengan jumlah penulis yang menulis artikel (Lotka, 1926). Semakin banyak artikel yang ditulis, semakin sedikit penulis yang menulisnya. Meskipun demikian menurut Potter (1981) dalil tersebut tidak selamanya dapat diterapkan, karena dibutuhkan jumlah data yang cukup banyak dan rentang waktu yang cukup panjang.Oleh karena itu beberapa kajian tentang produktivitas penulis yang dilakukan dengan menggunakan dalil Lotka, selalu dilakukan uji statistik menggunakan uji
Kolmogorov-Smirnov (Sivakumar, 2013; Pulgarin, 2012; Lin, 2011).

Publikasi majalah ilmiah bidang ilmu psikologi sudah banyak diterbitkan oleh perguruan tinggi negeri maupun swasta yang ada di Indonesia. Salah satunya adalah Fakultas Psikologi Universitas Gadjah Mada, yang sampai saat ini tetap eksis menerbitkan majalah ilmiah psikologi. Publikasi tersebut memuat artikel hasil penelitian dan hasil pemikiran karya sivitas akademika di lingkup internal maupun eksternal. Frekuensi keterlibatan penulis artikel di dalam penerbitan majalah ilmiah menunjukkan tinggi rendahnya partisipasi dan produktivitas mereka dalam mendukung eksistensi dan keberlangsungan penerbitannya. Ada dua judul majalah ilmiah yang telah dipublikasikan sampai saat ini, masing-masing berjudul Buletin Psikologi dan Jurnal Psikologi. Sejak penerbitan perdana yaitu tahun 1993 dan tahun 1985 sampai saat ini keduanya masih eksis dan lebih banyak kemajuan baik secara kuantitas maupun kualitas muatannya. Keberlangsungan penerbitan yang tetap eksis sampai saat ini, merupakan motivasi penulis untuk melakukan kajian terhadap kedua majalah ilmiah tersebut.

Pada kesempatan ini penulis mengkaji tentang produktivitas penulis artikel pada Jurnal Psikologi UGM (1985-2016) dan Buletin Psikologi UGM (1993-2015). Kajian ini juga sekaligus menguji aplikasi dalil Lotka berkaitan dengan produktivitas penulis. Pertanyaan yang diajukan dalam kajian ini antara lain:

1. Bagaimana produktivitas penulis artikel Jurnal Psikologi dan Buletin Psikologi Universitas Gadjah Mada?

2. Bagaimana hasil uji dalil Lotka terhadap produktivitas penulis artikel Jurnal Psikologi dan Buletin Psikologi Universitas Gadjah Mada?

3. Siapakah penulis artikel yang produktif pada kedua majalah ilmiah tersebut?

Kajian ini bertujuan untuk:

1. Mengetahui produktivitas penulis artikel Jurnal Psikologi dan Buletin Psikologi Universitas Gadjah Mada.

2. Mengetahui hasil uji dalil Lotka terhadap produktivitas penulis artikel 
Jurnal Psikologi dan Buletin Psikologi Universitas Gadjah Mada.

3. Mengetahui penulis artikel yang produktif pada kedua majalah ilmiah tersebut.

Manfaat yang diharapkan dari hasil kajian ini antara lain menambah khazanah kajian bibliometri khususnya dalam penggunaan dalil Lotka pada produktivitas penulis artikel majalah ilmiah psikologi yang diterbitkan Fakultas Psikologi Universitas Gadjah Mada.

Kajian produktivitas penulis pada majalah ilmiah perguruan tinggi berkaitan dengan pengujian terhadap dalil Lotka sudah banyak dilakukan baik di dalam maupun di luar negeri. Kajian di luar negeri antara lain dilakukan oleh Sivakumar (2013), Devi (2013), Pulgarin (2012), Lin (2011), serta Tsay (2004).

Pada tahun 2013, Sivakumar dan kawankawan menguji dalil Lotka dengan mengkaji produktivitas peneliti bidang ilmu Biologi di Central University of India. Hasil kajian menunjukkan bahwa temuannya tidak sesuai dengan dalil Lotka. Pada tahun yang sama Devi (2013) juga melakukan kajian untuk merevisi hasil kajian literatur toksikologi menggunakan dalil Lotka. Dalam kajian tersebut ditemukan bahwa dalil Lotka tidak sesuai dengan hasil pengamatan.

Berbeda dengan kajian yang dilakukan oleh Pulgarin (2012), ditemukan bahwa nilai eksponen (n) dan konstanta (c) di dalam dalil Lotka dipengaruhi oleh produktivitas penulis secara spesifik pada bidang ilmu tertentu.

Huang dan Yang (2012) melakukan kajian produktivitas penulis berkaitan dengan manajemen kinerja yang diambil dari database SSCI tahun 1976-2011, dan diperoleh 922 artikel untuk dianalisis. Salah satu temuannya menunjukkan bahwa parameter nilai $\mathbf{n}$ dan $\mathbf{c}$ dalam dalil Lotka masing-masing sebesar 3.7232 dan 0.8963. Setelah dilakukan uji Kolmogorov-Smirnov, membuktikan bahwa dalil Lotka berlaku untuk menjelaskan kecenderungan tren literatur dalam manajemen kinerja.

Lin dan kawan-kawan (2011) melakukan kajian mengenai pertumbuhan literatur dan produktivitas penulis dengan teknik bibliometri menggunakan dalil Lotka. Adapun publikasi yang dikaji berupa hasil-hasil penelitian berkaitan dengan theory of reasoned action (TRA), selama periode 1982-2009. Data diperoleh dari database Social Science Citation Index (SSCI), dan ditemukan hasil bahwa jumlah produksi literatur pada TRA masih terus meningkat. Amerika Serikat merupakan negara pengembang utama terkait dengan TRA, dengan literatur berbahasa Inggris menduduki peringkat tertinggi. Persentase penulis yang relatif tinggi yaitu $86,76 \%$ masing-masing menyumbangkan satu artikel. Persentase ini cenderung lebih tinggi dari $60 \%$ yang ditemukan dengan menggunakan dalil Lotka. Meskipun demikian berdasarkan hasil uji Kolmogorov-Smirnof (KS) menunjukkan bahwa distribusi indeks frekuensi produktivitas penulis sesuai dengan dalil Lotka.

Pada tahun 2010 Kumar juga melakukan kajian produktivitas ilmuwan di Council of Scientific and Industrial Research (CSIR) India, dengan basis data tahun 1988-1992 dan 20042008. Dalam kajian tersebut ditemukan bahwa produktivitas ilmuwan CSIR tidak sesuai dengan dalil Lotka.

Kajian yang lain dilakukan oleh Tsay (2004) mengenai pertumbuhan literatur, karakteristik jurnal, dan produktivitas penulis pada indeks subjek literatur 1977-2000, dengan basis data pada Library dan Information Science Abstract (LISA). Salah satu temuannya adalah bahwa sebagian besar penulis $(76,7 \%)$ hanya menyumbang satu artikel, dan persentase ini jauh lebih besar daripada $60 \%$ dalam data Lotka.

Di Indonesia kajian produktivitas penulis menggunakan dalil Lotka juga pernah dilakukan, antara lain dilakukan oleh Wahyudi dan kawan-kawan (2015) mengenai pola produktivitas penulis artikel bidang perpustakaan dan informasi di Indonesia. Dalam kajian tersebut sumber data menggunakan majalah ilmiah atau jurnal bidang ilmu perpustakaan dan informasi yang terdaftar pada pangkalan data PDII LIPI tahun 20012010 .Hasilnya menunjukkan bahwa berdasarkan uji Kolmogorov-Smirnov, distribusi produktivitas penulis bidang ilmu perpustakaan dan informasi di Indonesia tahun 
2001-2010 sesuai dengan dalil Lotka. Hal ini disebabkan tidak adanya perbedaan yang signifikan antara hasil pengamatan distribusi produktivitas dengan nilai teoretis dalil Lotka.

Kajian Anwar (2012) mengenai pola produktivitas penulis dalam jurnal yang terbit di lingkungan Fakultas Ilmu Sosial dan Politik di Universitas Airlangga. Kajian ini merupakan kajian bibliometri yang menggunakan dalil Lotka, dan ditemukan nilai eksponen sebesar 0,7767 . Setelah dilakukan uji statistik menggunakan Kolmogorov-Smirnov diperoleh nilai titik kritis sebesar 0,0962 dan nilai deviasi maksimum 0,0111. Karena nilai $\mathrm{D}_{\text {maks }}$ lebih kecil dari nilai titik kritisnya, berarti ada hubungan antara jumlah artikel dan jumlah penulis, atau dengan kata lain dalil Lotka bisa diterapkan untuk mengukur produktivitas penulis.

Pada tahun 2009, Nelisa juga melakukan kajian mengenai produktivitas penulis artikel bidang ilmu perpustakaan dan informasi di Indonesia tahun 1978-2007. Dalam kajian ini juga menggunakan dalil Lotka, dan hasilnya menunjukkan bahwa ada perbedaan yang signifikan antara nilai teoritis dalil Lotka dengan hasil pengamatan pada distribusi penulis artikel bidang ilmu perpustakaan dan informasi.

Uraian di atas menunjukkan bahwa kajian produktivitas penulis beberapa bidang ilmu pengetahuan dengan menggunakan dalil Lotka sudah pernah dilakukan di Indonesia. Namun kajian dalam bidang ilmu psikologi kemungkinan belum ada atau penulis belum berhasil menemukan artikel terkait. Oleh karena itu pada kesempatan ini penulis mencoba mengkaji produktivitas penulis menggunakan dalil Lotka, dalam lingkup yang masih terbatas yaitu pada media komunikasi ilmiah psikologi yang diterbitkan Fakultas Psikologi Universitas Gadjah Mada.

\section{B. TINJAUAN PUSTAKA \\ Bibliometri}

Komunikasi ilmiah di kalangan ilmuwan dapat terjadi secara langsung dan tidak langsung. Komunikasi tidak langsung antara ilmuwan dapat dilakukan melalui media seperti majalah ilmiah atau jurnal dan prosiding. Di samping manfaatnya sebagai media komunikasi, majalah ilmiah dapat dipergunakan sebagai sarana untuk mengetahui perkembangan bidang ilmu tertentu dalam kurun waktu tertentu.

Sebuah metode yang menggunakan majalah ilmiah sebagai objek kajian adalah bibliometri. Dikemukakan oleh Sulistyo-Basuki (2002), bahwa bibliometri pertama kali dikenalkan oleh Pritchard pada tahun 1969. Bibliometri bertujuan menjelaskan proses komunikasi tertulis, arah pengembangan sarana deskriptif, serta analisis berbagai faset komunikasi. Bibliometri dibagi menjadi dua kelompok yaitu distribusi publikasi dan analisis sitiran. Kelompok distribusi publikasi merupakan analisis kuantitatif terhadap literatur, yang ditandai dengan munculnya tiga dalil dasar bibliometri yaitu Lotka, Zipf, dan Bradford.

Dalil Lotka merupakan sebuah dalil yang menghitung distribusi produktivitas penulis. Berdasarkan hasil kajiannya beberapa waktu yang lalu, ditemukan bahwa ada hubungan terbalik antara jumlah artikel yang ditulis dengan jumlah penulis yang menulis artikel, yaitu semakin banyak artikel yang ditulis, semakin sedikit penulis yang menulisnya (Lotka, 1926).

Kajian-kajian selanjutnya yang dilakukan oleh para peneliti berkaitan dengan produktivitas penulis dalam berbagai bidang ilmu pengetahuan, menunjukkan hasil yang sesuai dengan dalil tersebut (Askew, 2008; Lin, 2011; Anwar, 2012; Wahyudi, 2015). Meskipun demikian, ada juga hasil kajian yang tidak sesuai dengan dalil tersebut. Beberapa di antaranya kajian yang dilakukan di luar maupun di dalam negeri (Nelisa, 2009; Kumar, 2010; Sivakumar, 2013; Sudhier, 2013; Kumar, 2014).

\section{Produktivitas Penulis}

Produktivitas merupakan kemampuan untuk menghasilkan sesuatu. Pada dasarnya produktivitas berawal dari kemauan, kemampuan, dan karakteristik personal. Kemauan dan kemampuan tersebut dapat membentuk perilaku produktif (Herawaty dan Budiharto, 2008). Produktivitas ilmiah merupakan kemampuan untuk menghasilkan suatu produk yang bersifat ilmiah dan 
berpengaruh terhadap perkembangan ilmu pengetahuan (Nelisa, 2009).

Di dalam buku berjudul Publication Manual American Psychological Association (APA, 2010) dikemukakan bahwa penulis adalah orang yang memberikan kontribusi besar dan bertanggung jawab atas sebuah karya yang diterbitkan. Dikemukakan pula bahwa kepenulisan juga mencakup mereka yang memberikan kontribusi ilmiah yang substansial.

Berdasarkan uraian di atas, dapat disimpulkan bahwa produktivitas penulis merupakan kemampuan dan kemauan seseorang untuk membuat karya tulis baik berupa hasil penelitian atau kritik karya sesuai bidang yang diminati. Pembuatan karya tulis ini dapat dilakukan secara individual atau mandiri dan atau kolaborasi.

\section{Media Komunikasi Ilmiah Psikologi Universitas Gadjah Mada}

Majalah ilmiah merupakan publikasi ilmiah berkala yang wajib dimiliki atau diterbitkan oleh setiap institusi perguruan tinggi. Selain sebagai media komunikasi ilmiah bidang ilmu psikologi, majalah ilmiah bermanfaat untuk mendiseminasikan karya-karya ilmiah yang dihasilkan oleh institusi tersebut. Pada umumnya muatan majalah ilmiah berupa karyakarya hasil penelitian dan/atau karya-karya kritik dan pandangan ilmiah para pakar dalam bidang ilmu tertentu. Oleh karena itu majalah ilmiah merupakan salah satu media komunikasi ilmiah yang perlu mendapat perhatian untuk pemantauan dan pengembangan ilmu pengetahuan dalam bidang tertentu.

Berkaitan dengan bidang ilmu psikologi, Fakultas Psikologi Universitas Gadjah Mada telah menerbitkan dua judul majalah ilmiah yaitu Buletin Psikologi dan Jurnal Psikologi. Kedua majalah tersebut berbentuk cetak, namun demikian bentuk file atau non-cetak tersedia juga di website Fakultas Psikologi UGM. Seperti tercantum dalam halaman kolofon disebutkan bahwa: Buletin Psikologi memuat artikel-artikel ilmiah populer, resensi buku, analisis, dan diskusi, pembahasan dan isu mengenai psikologi dan bidang-bidang yang relevan baik dari segi teori maupun aplikasi praktisnya (Fakultas Psikologi UGM, 1993).

Muatan informasi pada Jurnal Psikologi yang diterbitkan Fakultas Psikologi UGM lebih menekankan pada artikel hasil penelitian baik menggunakan pendekatan kuantitatif maupun kualitatif yang dilakukan secara individual maupun kelompok (Fakultas Psikologi UGM, 2009).

Berkaitan dengan penerbitan kedua majalah tersebut, ada beberapa ketentuan yang harus dipenuhi oleh setiap penulis yang ingin mempublikasikan karyanya pada majalah tersebut. Adapun ketentuan yang perlu diperhatikan oleh para penulis antara lain, penulisan artikel mengacu pada Publication Manual of the American Psychologial Association (APA), dapat disajikan dalam bahasa Indonesia atau bahasa Inggris dengan menggunakan kaidah tata bahasa yang baik dan benar, panjang manuskrip 15-20 halaman termasuk ilustrasi yang menyertai (Fakultas Psikologi UGM, 2016).

Buletin Psikologi dan Jurnal Psikologi Universitas Gadjah Mada masing-masing diterbitkan dua kali dalam setahun. Meskipun demikian ada beberapa nomor penerbitan yang kosong khususnya untuk nomor-nomor lama. Hal ini dikarenakan pengurus majalah ilmiah pada waktu itu secara penuh dilaksanakan oleh staf pengajar yang tentunya juga memiliki kesibukan mengajar. Pada tahun 2000 dan seterusnya penerbitannya lebih teratur karena ditangani oleh staf administrasi khusus jurnal, meskipun pimpinan reaksi dan tim reviewer dipegang oleh staf pengajar.

\section{METODE PENELITIAN}

Kajian ini menggunakan pendekatan kuantitatif dengan analisis bibliometri untuk menguji dalil Lotka pada produktivitas penulis majalah ilmiah psikologi yang diterbitkan Fakultas Psikologi Universitas Gadjah Mada. Subjek kajiannya meliputi Jurnal Psikologi dan Buletin Psikologi Universitas Gadjah Mada yang masih tersedia di perpustakaan fakultas. Objek kajiannya adalah penulis artikel yang dimuat pada kedua majalah ilmiah tersebut.

Populasi kajian meliputi semua artikel yang dimuat pada Buletin Psikologi tahun 1993- 
2015 dan Jurnal Psikologi tahun 1985-2016. Metode pengumpulan data menggunakan metode dokumentasi, yaitu mengumpulkan data berupa catatan, transkrip, buku, surat kabar, majalah dan sebagainya. Metode ini tidak terlalu sulit karena apabila ada kekeliruan, sumber datanya masih tetap atau belum berubah (Arikunto, 2010).

Meskipun data yang dikumpulkan untuk majalah Buletin Psikologi selama periode 19932015, perlu dijelaskan di sini bahwa analisis data dilakukan dengan langkah-langkah sebagai berikut:

1. Mengukur produktivitas penulis artikel pada dua majalah ilmiah Psikologi UGM dengan dalil Lotka: (a) melibatkan penulis utama (straight count), (b) melibatkan semua penulis (complete count).

2. Menentukan nilai pendugaan parameter Lotka $\mathbf{n}$ dan $\mathbf{C}$, dengan rumus-rumus berikut.

Rumus untuk menentukan nilai $\boldsymbol{n}$ sebagai berikut

$$
b=\frac{\sum(x-\bar{x})(y-\bar{y})}{\sum(x-\bar{x})^{2}}
$$

Rumus untuk menentukan nilai $\mathbf{C}$ sebagai berikut

$$
C=\frac{1}{\sum \frac{1}{x^{2}}}
$$

3. Menghitung distribusi teoritis dalil Lotka, dengan rumus sebagai berikut:

$$
Y_{x}=\frac{C}{x^{n}}
$$

4. Melakukan uji Kolmogorof Smirnov (uji KS) untuk mengetahui deviasi maksimum $\left(\mathrm{D}_{\text {maks }}\right)$. Nilai $\mathrm{D}_{\text {maks }}$ merupakan deviasi mutlak yang merupakan selisih positif tertinggi antara frekuensi harapan (teoritis) dan frekuensi pengamatan. Nilai ini untuk membuat dugaan mengenai keeratan antara distribusi frekuensi pengamatan dengan distribusi frekuensi teoritis. Peluang distribusi $\mathrm{D}_{\text {maks }}$ tidak tergantung pada banyaknya sampel yang digunakan dan tidak tergantung dari distribusi frekuensi reoritis (Mustafa, 2009).

Semua perhitungan analisis data menggunakan bantuan program komputer Microsoft Excel.

\section{HASIL DAN PEMBAHASAN}

Seperti dikemukakan pada bab sebelumnya bahwa meskipun penerbitan kedua majalah ilmiah tersebut dua kali dalam setahun, akan tetapi penerbitannya masih ada yang kosong atau tidak terbit karena kendala teknis. Oleh karena itu data yang berhasil dikumpulkan tidak maksimal. Jurnal Psikologi Universitas Gadjah Mada periode 1985-2016 yang berhasil dikumpulkan ada 50 nomor penerbitan, sedangkan Buletin Psikologi Universitas Gadjah Mada 1993-2015 ada 42 nomor.

Setelah dilakukan pengumpulan data pada kedua majalah ilmiah tersebut, yaitu Jurnal Psikologi tahun 1985-2016 dan Buletin

\begin{tabular}{|c|c|c|c|}
\hline \multirow{2}{*}{ Judul Majalah } & \multirow{2}{*}{ Periode } & \multicolumn{2}{|c|}{ Jumlah Penulis } \\
\hline & & Straight Count & $\begin{array}{c}\text { Complete } \\
\text { Count }\end{array}$ \\
\hline Jurnal Psikologi & $1985-2016$ & 204 & 293 \\
\hline Buletin Psikologi & $1993-2015$ & 124 & 129 \\
\hline
\end{tabular}
Psikologi 1993-2015, diperoleh data seperti disajikan pada Tabel 1.

Sumber: data diolah, 2017

Berdasarkan data pada Tabel 1 kemudian dilakukan penghitungan untuk pendugaan parameter dalil Lotka dengan melibatkan penulis pertama (straight count), dan kemudian seluruh penulis (complete count) baik pada Jurnal Psikologi maupun Buletin Psikologi.

\section{Produktivitas penulis Jurnal Psikologi Universitas Gadjah Mada \\ a. Pelibatan penulis pertama (straight count)}

Setelah dilakukan penghitungan jumlah penulis dengan straight count atau penulis pertama dan mengabaikan penulis tambahan, diperoleh data untuk menghitung pendugaan 
parameter dalil Lotka seperti terlihat pada Tabel 2. Kolom dua dan tiga masing-masing menyajikan jumlah artikel dan jumlah penulis pertama. Jumlah artikel menunjukkan produktivitas artikel yang dihasilkan oleh penulis pada kolom tiga selama 31 tahun. Kolom empat dan lima masing-masing merupakan penghitungan logaritma dari artikel dan penulis.

Berdasarkan data pada Tabel 2 selanjutnya dihitung nilai $\mathrm{n}$ dan nilai $\mathrm{C}$ menggunakan rumus yang sudah ada dan menghasilkan nilai $\mathrm{n}=$ 2.1794 dan nilai $\mathrm{C}=0.7034$. Kedua nilai tersebut dipergunakan untuk melakukan penghitungan produkivitas penulis artikel Jurnal Psikologi menggunakan dalil Lotka.

Tabel 2 Perhitungan pendugaan parameter dalil Lotka untuk penulis artikel (straight count) Jurnal Psikologi UGM 1985-2016

\begin{tabular}{ccccccc}
\hline No. & Artikel (x) & $\begin{array}{c}\text { Penulis } \\
(\mathrm{y})\end{array}$ & $\mathrm{X}=(\log \mathrm{Y}=(\log \mathrm{y})$ & $\mathrm{XY}$ & $\mathrm{X}^{2}$ \\
\hline 1 & 1 & 157 & 0 & 2.19589 & 0 & 0 \\
2 & 2 & 25 & 0.30102 & 1.39794 & 0.42082 & 0.09061 \\
3 & 3 & 9 & 0.47712 & 0.95424 & 0.45528 & 0.22764 \\
4 & 4 & 6 & 0.60205 & 0.77815 & 0.46849 & 0.36247 \\
5 & 5 & 2 & 0.69897 & 0.30102 & 0.21041 & 0.48855 \\
6 & 6 & 3 & 0.77815 & 0.47712 & 0.37127 & 0.60551 \\
7 & 8 & 2 & 0.90308 & 0.30102 & 0.27185 & 0.81557 \\
\hline & Total & 204 & 3.76039 & 6.40538 & 2.19812 & 2.59035 \\
\hline
\end{tabular}

Selanjutnya dilakukan penghitungan produktivitas penulis artikel Jurnal Psikologi UGM menggunakan dalil Lotka dan penghitungan produktivitas penulis artikel dengan pengamatan biasa. Hasil penghitungan berdasarkan teori dan pengamatan tersebut disajikan pada Tabel3.

Tabel 3

Distribusi penulis berdasarkan dalil Lotka dan pengamatan

\begin{tabular}{ccccc}
\hline No. & Artikel $(\mathrm{x})$ & Penulis $(\mathrm{y})$ & Lotka $(\mathrm{Yx})$ & Pengamatan \\
\hline 1 & 1 & 157 & 0.7034 & 0.76961 \\
2 & 2 & 25 & 0.1553 & 0.12255 \\
3 & 3 & 9 & 0.06418 & 0.04412 \\
4 & 4 & 6 & 0.0343 & 0.02941 \\
5 & 5 & 2 & 0.02109 & 0.0098 \\
6 & 6 & 3 & 0.01417 & 0.01471 \\
7 & 8 & 2 & 0.00756 & 0.0098 \\
\hline \multicolumn{5}{c}{ Total } \\
\hline
\end{tabular}

Tabel 3

Distribusi penulis berdasarkan dalil Lotka dan pengamatan

\begin{tabular}{ccccc}
\hline No. & Artikel (x) & Penulis (y) & Lotka (Yx) & Pengamatan \\
\hline 1 & 1 & 157 & 0.7034 & 0.76961 \\
2 & 2 & 25 & 0.1553 & 0.12255 \\
3 & 3 & 9 & 0.06418 & 0.04412 \\
4 & 4 & 6 & 0.0343 & 0.02941 \\
5 & 5 & 2 & 0.02109 & 0.0098 \\
6 & 6 & 3 & 0.01417 & 0.01471 \\
7 & 8 & 2 & 0.00756 & 0.0098 \\
\hline \multicolumn{5}{c}{} \\
\hline
\end{tabular}

Menguji hasil penghitungan produktivitas penulis artikel Jurnal Psikologi UGM menggunakan dalil Lotka perlu dilakukan uji Kolmogorov-Smirnov (K-S). Hasil uji tersebut disajikan pada Tabel 4.

\begin{tabular}{ccccccccc}
\multicolumn{8}{c}{ Tabel 4 Hasil uji Kolmogorov-Smirnov produktivitas } \\
penulis pertama (straight count) Jurnal Psikologi \\
1985-2016
\end{tabular}

Pada Tabel 4 menunjukkan bahwa Deviasi maksimum 0.06621 , dan nilai kritis $\mathrm{K}-\mathrm{S}=$ 0.09521. Karena Dmaks lebih kecil dari nilai kritis yaitu $0.06621<0.09521$ menunjukkan bahwa produktivitas penulis artikel pada Jurnal Psikologi UGM 1985 -2016, dengan hanya melibatkan penulis pertama (straight count) hasilnya sesuai dengan dalil Lotka.

Temuan ini mendukung kajian yang pernah dilakukan oleh peneliti sebelumnya yaitu Huang dan Yang (2011), dalam kajiannya terhadap produktivitas penulis pada database SSCI selama 35 tahun berkaitan dengan bidang manajemen kinerja. Diprediksikan bahwa adanya kesesuaian ini terjadi karena periode 
yang melebihi 10 tahun terhadap objek yang dikaji berupa majalah atau publikasi ilmiah.

\section{b. Keterlibatan penulis secara keseluruhan (complete count)}

Berbeda dengan penghitungan menggunakan data penulis secara keseluruhan (complete count), diperoleh data untuk penghitungan pendugaan parameter dalil Lotka seperti tercantum pada Tabel 5. Pada tabel tersebut menunjukkan penulis yang terlibat berjumlah 293. Adapun susunan kolom pada Tabel 5 sama seperti pada tabel sebelumnya (Tabel 2)

Tabel 5 Perhitungan untuk pendugaan parameter dalil Lotka penulis artikel (complete count) Jurnal Psikologi UGM

\begin{tabular}{ccccccc}
\hline \multirow{2}{*}{ No } & $\begin{array}{c}\text { Artikel Penulis } \\
(\mathrm{x})\end{array}$ & $(\mathrm{y})$ & $\mathrm{X}$ & $\mathrm{Y}$ & $\mathrm{XY}$ & $\mathrm{X}^{2}$ \\
\hline 1 & 1 & 220 & 0 & 2.34242 & 0 & 0 \\
2 & 2 & 27 & 0.30102 & 1.43136 & 0.43088 & 0.09061 \\
3 & 3 & 10 & 0.47712 & 1 & 0.47712 & 0.22764 \\
4 & 4 & 9 & 0.60205 & 0.95424 & 0.57451 & 0.36247 \\
5 & 5 & 5 & 0.69897 & 0.69897 & 0.48855 & 0.48855 \\
6 & 6 & 4 & 0.77815 & 0.60205 & 0.46849 & 0.60551 \\
7 & 7 & 4 & 0.84509 & 0.60205 & 0.50879 & 0.71419 \\
8 & 8 & 3 & 0.90308 & 0.47712 & 0.43088 & 0.81557 \\
9 & 9 & 3 & 0.95424 & 0.47712 & 0.45528 & 0.91057 \\
10 & 10 & 2 & 1 & 0.30102 & 0.30102 & 1 \\
11 & 11 & 2 & 1.04139 & 0.30102 & 0.31349 & 1.08449 \\
12 & 12 & 2 & 1.07918 & 0.30102 & 0.32486 & 1.16463 \\
13 & 14 & 1 & 1.11394 & 0 & 0 & 1.24086 \\
14 & 15 & 1 & 1.14612 & 0 & 0 & 1.31360 \\
\hline & Total & 293 & 10.94035 & 9.48839 & 7.77387 & 10.01869 \\
\hline & & & & & &
\end{tabular}

Berdasarkan data pada Tabel 5, diperoleh nilai $\mathrm{n}=1.79738$ dan nilai $\mathrm{C}=0.57249$. Kedua nilai tersebut selanjutnya dapat digunakan untuk penghitungan produktivitas penulis Jurnal Psikologi Universitas Gadjah Mada dengan melibatkan seluruh penulis (complete count) menggunakan dalil Lotka. Di samping penghitungan produktivitas menggunakan dalil Lotka juga dilakukan penghitungan dengan pengamatan biasa. Kedua hasil penghitungan tersebut diperlukan untuk melakukan uji Kolmogorof-Smirnov (uji K-S). Hasil uji K-S selengkapnya disajikan pada Tabel 6 .

Pada Tabel 6 menunjukkan bahwa deviasi maksimum $\left(\mathrm{D}_{\text {maks }}\right)$ sebesar 0.10293 , sedangkan nilai titik kritis K-S adalah $=0.07945$. Kondisi ini menunjukkan bahwa Dmaks lebih besar dari nilai titik kritis yaitu $0.10293>0.07945$ berarti produktivitas penulis artikel Jurnal Psikologi UGM dengan menghitung seluruh penulis (complete account) tidak sesuai dengan dalil Lotka.

Tabel 6 Hasil uji Kolmogorov-Smirnov produktivitas seluruh penulis (complete count) Jurnal Psikologi

\begin{tabular}{|c|c|c|c|c|c|c|c|}
\hline No & $\begin{array}{l}\text { Artikel } \\
(\mathrm{x})\end{array}$ & $\begin{array}{c}\text { Penulis } \\
\text { (y) }\end{array}$ & Lotka & Kumulatif & Pengamatan & $\begin{array}{c}\text { Kumula } \\
\text { tif }\end{array}$ & Uji K-S \\
\hline 1 & 1 & 220 & 0.57249 & 0.57249 & 0.74829 & 0.74829 & 0.1758 \\
\hline 2 & 2 & 27 & 0.16471 & 0.7372 & 0.09184 & 0.84013 & 0.10293 \\
\hline 3 & 3 & 10 & 0.07947 & 0.81667 & 0.03402 & 0.87415 & 0.05748 \\
\hline 4 & 4 & 9 & 0.04738 & 0.86405 & 0.03062 & 0.90477 & 0.04072 \\
\hline 5 & 5 & 5 & 0.03173 & 0.89578 & 0.01701 & 0.92178 & 0.026 \\
\hline 6 & 6 & 4 & 0.02287 & 0.91865 & 0.0136 & 0.93538 & 0.01673 \\
\hline 7 & 7 & 4 & 0.01734 & 0.93599 & 0.0136 & 0.94898 & 0.01299 \\
\hline 8 & 8 & 3 & 0.01363 & 0.94962 & 0.01021 & 0.95919 & 0.00957 \\
\hline 9 & 9 & 3 & 0.01103 & 0.96065 & 0.01021 & 0.9694 & 0.00875 \\
\hline 10 & 10 & 2 & 0.00912 & 0.96977 & 0.0068 & 0.9762 & 0.00643 \\
\hline 11 & 11 & 2 & 0.00769 & 0.97746 & 0.0068 & 0.983 & 0.00554 \\
\hline 12 & 12 & 2 & 0.00657 & 0.98403 & 0.0068 & 0.9898 & 0.00577 \\
\hline 13 & 14 & 1 & 0.00499 & 0.98902 & 0.0034 & 0.9932 & 0.00418 \\
\hline \multirow[t]{2}{*}{14} & 15 & 1 & 0.00441 & 0.99343 & 0.0034 & 0.9966 & 0.00317 \\
\hline & Total & 293 & & & & & \\
\hline
\end{tabular}

Temuan ini mendukung kajian sebelumnya yang dilakukan oleh Nelisa (2009), terhadap produktivitas penulis bidang ilmu perpustakaan dan informasi selama 29 tahun. Adanya perbedaan yang signifikan antara hasil pengamatan dan teori diprediksikan karena penghitungan dengan melibatkan seluruh penulis, sementara kajian yang dilakukan Lotka hanya terbatas pada penulis pertama (Askew, 2008).

\section{Produktivitas penulis Buletin Psikologi Universitas Gadjah Mada}

a. Pelibatan penulis pertama (straight count)

Jumlah penulis artikel Buletin Psikologi Universitas Gadjah Mada 1993-2015 yang dihitung secara straight count ada 124. Selanjutnya dilakukan penghitungan logaritma terhadap masing-masing jumlah artikel dan jumlah penulis, hasilnya tercantum pada kolom empat dan lima dalam Tabel 7. Penghitungan tersebut dilakukan untuk menentukan nilai eksponen (n) dan nilai C. 
Tabel 7 Perhitungan untuk pendugaan parameter dalil Lotka penulis artikel (straight count) Buletin Psikologi

\begin{tabular}{|c|c|c|c|c|c|c|}
\hline No. & Karya (x) & Penulis (y) & $\mathrm{X}$ & $\mathrm{Y}$ & $\mathrm{XY}$ & $\mathrm{X}^{2}$ \\
\hline 1 & 1 & 89 & 0 & 1.94939 & 0 & 0 \\
\hline 2 & 2 & 18 & 0.30103 & 1.25527 & 0.37787 & 0.09061 \\
\hline 3 & 3 & 3 & 0.47712 & 0.47712 & 0.22764 & 0.22764 \\
\hline 4 & 4 & 5 & 0.60206 & 0.69897 & 0.42082 & 0.36247 \\
\hline 5 & 5 & 4 & 0.69897 & 0.60206 & 0.42082 & 0.48855 \\
\hline 6 & 6 & 1 & 0.77815 & 0 & 0 & 0.60551 \\
\hline 7 & 8 & 1 & 0.90309 & 0 & 0 & 0.81557 \\
\hline 8 & 9 & 1 & 0.95424 & 0 & 0 & 0.91057 \\
\hline 9 & 10 & 1 & 1 & 0 & 0 & 1 \\
\hline \multirow[t]{2}{*}{10} & 17 & 1 & 1.23044 & 0 & 0 & 1.514 \\
\hline & Total & 124 & 6.9451 & 4.98281 & 1.44715 & 6.01492 \\
\hline
\end{tabular}

Berdasarkan data pada Tabel 7, diperoleh nilai $\mathrm{n}$ sebesar 1.6898 , dan nilai $\mathrm{C}$ sebesar 0.5683 . Kedua nilai tersebut selanjutnya dipergunakan untuk penghitungan produktivitas penulis Buletin Psikologi UGM 1993-2015 (straight count) dengan dalil Lotka. Penghitungan produktivitas dengan cara pengamatan atau biasa juga harus dilakukan terhadap produktivitas majalah tersebut. Kedua hasil penghitungan tersebut dipergunakan untuk melakukan uji Kolmogorov-Smirnov (uji K-S). Hasil uji K-S selengkapnya disajikan pada Tabel 8.

Pada Tabel 8 menunjukkan bahwa deviasi maksimum $\mathrm{D}_{\text {maks }}=0.14944$. Setelah dilakukan penghitungan nilai titik kritis K-S ditemukan nilai sebesar $=0.12213$. Hal ini menunjukkan bahwa $\mathrm{D}_{\text {maks }}$ lebih besar dari titik kritis K-S, yaitu $0.14944>0.12213$ dengan demikian hasil pengujian ini tidak sesuai dengan dalil Lotka.

Temuan ini mendukung sekaligus menolak atau berseberangan dengan beberapa kajian yang dilakukan sebelumnya. Kajian sebelumnya yang mendukung yaitu Nelisa (2009) menemukan adanya perbedaan yang signifikan antara produktivitas penulis hasil pengamatan dan hasil teoretis. Sementara hasil kajian yang berseberangan yaitu Potter (1981) bahwa kajian harus dilakukan pada penulis pertama, seperti yang dilakukan pada kajian ini.
Tabel 8 Hasil uji Kolmogorov-Smirnov untuk penulis pertama artikel Buletin Psikologi UGM 1993-2015

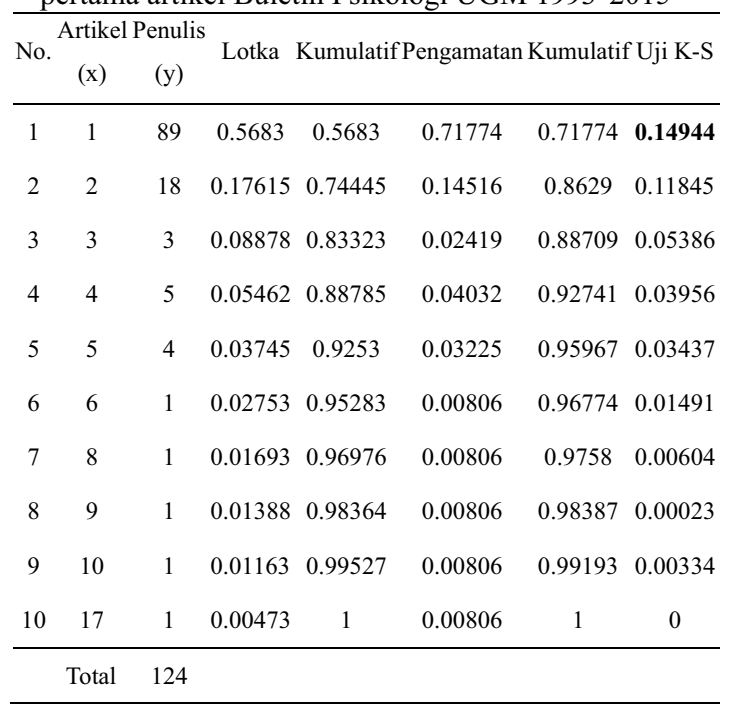

\section{b. Keterlibatan penulis secara keseluruhan (complete count)}

Apabila seluruh penulis artikel dihitung (complete account), ada 129 penulis yang terlibat. Selanjutnya dilakukan penghitungan logaritma untuk masing-masing distribusi artikel dan penulis, dan hasilnya seperti tercantum pada kolom empat dan lima dalam Tabel 9.

\begin{tabular}{|c|c|c|c|c|c|c|}
\hline No. & Karya (x) & Penulis (y) & $\mathrm{X}$ & $\mathrm{Y}$ & $X Y$ & $\mathrm{X}^{2}$ \\
\hline 1 & 1 & 92 & 0 & 1.96378 & 0 & 0 \\
\hline 2 & 2 & 18 & 0.30102 & 1.25527 & 0.37787 & 0.09061 \\
\hline 3 & 3 & 5 & 0.47712 & 0.69897 & 0.33349 & 0.22764 \\
\hline 4 & 4 & 5 & 0.60205 & 0.69897 & 0.42082 & 0.36247 \\
\hline 5 & 5 & 4 & 0.69897 & 0.60205 & 0.42082 & 0.48855 \\
\hline 6 & 6 & 1 & 0.77815 & 0 & 0 & 0.60551 \\
\hline 7 & 8 & 1 & 0.90308 & 0 & 0 & 0.81557 \\
\hline 8 & 11 & 1 & 1.04139 & 0 & 0 & 1.08448 \\
\hline 9 & 13 & 1 & 1.11394 & 0 & 0 & 1.24086 \\
\hline \multirow[t]{2}{*}{10} & 17 & 1 & 1.23044 & 0 & 0 & 1.514 \\
\hline & Jumlah & 129 & 7.14616 & 5.21904 & 1.553 & 6.42969 \\
\hline
\end{tabular}


Demikian halnya untuk kolom enam dan tujuh pada tabel yang sama merupakan hasil penghitungan yang diperlukan untuk menentukan nilai $\mathrm{n}$ dan $\mathrm{C}$. Berdasarkan perhitungan dengan menggunakan data pada Tabel 9, diperoleh nilai $\mathrm{n}$ sebesar 1,6453, dan nilai $\mathrm{C}$ sebesar 0.5601 untuk menghitung produktivitas menggunakan dalil Lotka.Selain menggunakan dalil Lotka, penghitungan produktivitas penulis Buletin Psikologi UGM 1993-2015 juga dilakukan dengan pengamatan.Kedua hasil tersebut diperlukan untuk melakukan uji K-S, seperti disajikan pada Tabel 10.

Tabel $10 \quad$ Uji Kolmogorov -Smirnov produktivitas penulis artikel ( complete count ) Buletin Psikologi UGM 1993-2015

\begin{tabular}{ccccccccc}
\hline \multirow{2}{*}{ No. $\begin{array}{c}\text { Karya } \\
(\mathrm{x})\end{array}$} & $\begin{array}{c}\text { Penulis } \\
\text { (y) }\end{array}$ & \multicolumn{6}{c}{ Prod.Lotka } & \multicolumn{5}{c}{ Kumulatif Pengamatan Kumulatif Uji K-S } \\
\hline 1 & 1 & 92 & 0.5601 & 0.5601 & 0.71317 & 0.71317 & $\mathbf{0 . 1 5 3 0 7}$ \\
2 & 2 & 18 & 0.17905 & 0.73915 & 0.13953 & 0.8527 & 0.11355 \\
3 & 3 & 5 & 0.09188 & 0.83103 & 0.03875 & 0.89145 & 0.06042 \\
4 & 4 & 5 & 0.05723 & 0.88826 & 0.03875 & 0.9302 & 0.04194 \\
5 & 5 & 4 & 0.03965 & 0.92791 & 0.03105 & 0.96125 & 0.03334 \\
6 & 6 & 1 & 0.02937 & 0.95728 & 0.00775 & 0.969 & 0.01172 \\
7 & 8 & 1 & 0.01829 & 0.97557 & 0.00775 & 0.97675 & 0.00118 \\
8 & 11 & 1 & 0.01083 & 0.9864 & 0.00775 & 0.9845 & 0.0019 \\
9 & 13 & 1 & 0.00823 & 0.99463 & 0.00775 & 0.99225 & 0.00238 \\
10 & 17 & 1 & 0.00528 & 1 & 0.00775 & 1 & 0 \\
\hline
\end{tabular}

Jumlah 129

Pada tabel 10 menunjukkan bahwa deviasi maksimum $\mathrm{D}_{\text {maks }}=0.15307$, sedangkan titik kritisnya sebesar 0.11974. Dengan demikian $\mathrm{D}_{\text {maks }}$ lebih besar daripada titik kritisnya yaitu $0.15307>0.11974$, berarti hasil ini tidak sesuai dengan dalil Lotka.

Temuan ini mendukung beberapa kajian yang dilakukan sebelumnya, antara lain Sudhier (2013) yang menemukan bahwa pelibatan penulis bidang ilmu Fisika secara straight count maupun complete count dalam penghitungan produktivitas, keduanya tidak sesuai dengan dalil Lotka.

\section{Penulis produktif pada Jurnal Psikologi dan Buletin Psikologi UGM}

Setelah dilakukan penggabungan data semua pemulis yang terlibat dalam artikel dua majalah ilmiah tersebut, diperoleh lima besar nama penulis produktif yang disajikan dalam gambar 1.

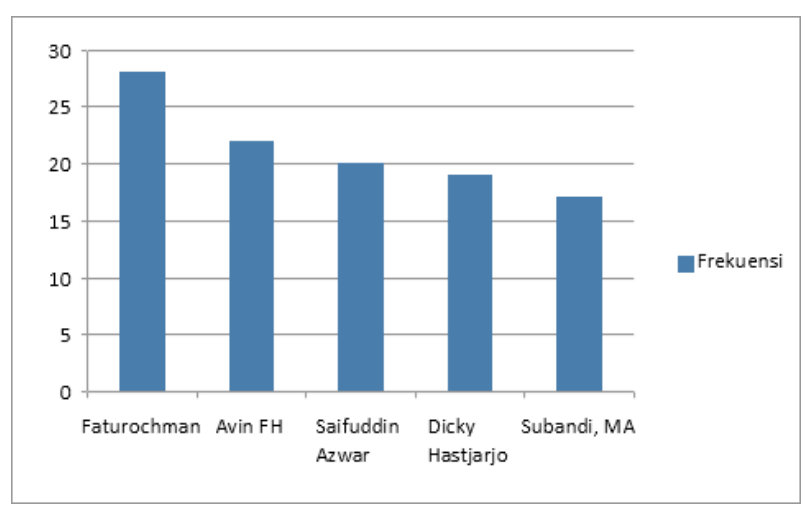

Gambar 1: Lima besar penulis produktif

Pada gambar 1 terlihat bahwa Faturcohman mencapai posisi tertinggiyaitu dalam 28 artikel, diikuti oleh Avin FH dalam 22 artikel, kemudian Saifuddin Azwar dalam 20 artikel, dan Dicky Hastjarjo serta Subandi masing-masing sebanyak 10 artikel dan 17 artikel.

\section{E. KESIMPULAN \\ Kesimpulan}

Berdasarkan hasil analisis data disimpulkan sebagai berikut.

1. Pengujian dalil Lotka pada Jurnal Psikologi

Apabila penghitungan dibatasi pada penulis pertama dan mengabaikan penulis tambahan menunjukkan bahwa produktivitas hasil pengamatan sesuai dengan produktivitas yang dihitung menggunakan dalil Lotka. Uji KolmogorovSmirnov menunjukkan $\mathrm{D}_{\text {maks }} 0.06621<$ 0.09521, dengan demikian dalil Lotka dapat diterima.

Apabila semua penulis dilibatkan dalam perhitungan, hasilnya menunjukkan bahwa uji Kolmogorov-Smirnov $\mathrm{D}_{\text {maks }}$ lebih besar daripada nilai titik kritis yaitu $0.10293>$ 0.07945, berarti dalil Lotka tidak dapat diterima.

2. Pengujian dalil Lotka pada Buletin Psikologi

Penghitungan dengan melibatkan penulis pertama maupun seluruh penulis menunjukkan bahwa $\mathrm{D}_{\text {maks }}$ lebih tinggi daripada nilai titik kritis. Rincian masingmasing adalah $0.14944>0.12213$ untuk 
straight count, dan $0.15307>0.11974$ untuk complete count.

3. Penulis yang paling produktif pada dua majalah ilmiah tersebut adalah Faturochman.

\section{Saran}

Dalil Lotka tidak sepenuhnya dapat dipergunakan untuk mengukur produktivitas penulis dalam berbagai bidang ilmu. Oleh karena itu kepada pemerhati yang tertarik untuk melakukan kajian produktivitas penulis menggunakan dalil Lotka, sebaiknya dilakukan pula dengan teknik yang lain sebagai pembanding, dengan harapan diperoleh hasil yang optimal.

\section{DAFTAR PUSTAKA}

American Psychological Association (2010). Publication manual of the American Psychological Association. Washington DC: APA.

Arikunto, S. (2010). Prosedur Penelitian. Suatu Pendekatan Praktik. Jakarta: Rineka Cipta.

Askew, C.A. (2008). An Examination of Lotka's law in the field of library and information studies (disertasi). Florida International University.

Anwar, C.M. (2012). Pola produktivitas pengarang dalam jurnal di Fakultas Ilmu Sosial dan Ilmu Politik Universitas Airlangga tahun 2009-2012. Diunduh dari: journal.unair.ac.id. pada tanggal 28 Juni 2017.

Devi, M. (2013). Lotka's law revisited in toxicology literature. Diunduh dari: Library Philosophy and Practice (e-journal), Paper 1019. pada tanggal 28 Juni 2017.

Fakultas Psikologi UGM. (1993). Buletin Psikologi, 1, (2), i.

Fakultas Psikologi UGM. (2009). Format penulisan naskah Jurnal Psikologi Universitas Gadjah Mada. Jurnal Psikologi, 36, (1), 93-94.

Fakultas Psikologi UGM. (2016). Format penulisan naskah Jurnal Psikologi UGM. Jurnal Psikologi, 43, (1), 84-87
Han-Chou Lin, Chih-Lun Wu, and Jiann-Min Yang (2011). A productivity review study on theory of reasoned action literature using bibliometric methodology. Paper, on International Conference on Management and Service Science IPEDR. 8, 38-42.

Herawaty, E. dan Budiharto, S. (2008). Hubungan antara kebermaknaan hidup dengan perilaku produktif pada guru SLB. Phronesis Jurnal Ilmiah Psikologi Industri dan Organisasi. 10, (1), 45-53.

Huang, Shu-Hsing and Jiann-Min Yang. (2012). A Study on the productivity review for management of performance methodology using bibliometric. Papers, on Eleventh Wuhan International Conference on eBusiness

Lotka, A.J. (1926). The frequency distribution of scientific productivity. Journal of the Washington Academy of Sciences, 16: 317323.

Kumar, N. (2010). Applicability to Lotka's law to research productivity of Council of Scientific and Industrial Research (CSIR), India. Annals of Library and Information Studies 57, 166-168.

Kumar, S. (2014). Author productivity in the field of Human Computer Interaction (HCI) research. Annals of Library and Information Studies. 61, 273-285.

Mustafa, B. (2009). Hukum Lotka mengenai produktivitas pengarang. Diunduh dari http://repository.ipb.ac.id/handle/12345678 9/32126 pada tanggal 12 Mei 2017

Nelisa, M. (2009). Produktivitas pengarang artikel bidang ilmu perpustakaan dan informasi di Indonesia tahun 1978-2007: Analisis bibliometrika menggunakan hukum Lotka. Baca, 30, (2), 73-95,

Potter, WG. (1981) Lotka's law revisited library trends 30, (1), 21-39. Diunduh dari http://www.ideals.illinois.edu, pada tanggal 2 Juni 2017

Pulgarin, A. (2012). Dependence of Lotka's law parameters on the scientific area. Malaysian Journal of Library \& Information Science.17, (1), 41-50. 
Purnomowati, S. (2001).Kondisi majalah Indonesia bidang ilmu perpustakaan dan informasi di awal abad 21. Baca, 26, (1-3), 27-31.

Sivakumar, N., Sivaraman, P., and Tamilselvan, N. (2013). Application of Lotka's Law in Biology literature of Central Universities in India. International Journal of Library and Information Science. 2, (1), 61-70.

Sudhier, K.G.P. (2013). Lotka's law and pattern of author productivity in the area of physics research. DESIDOC Journal of Library \& Information Technology. 33, (6), 457-464.
Tsay, Ming-Yueh. (2004). Literature growth, journal characteristics and author productivity in subject indexing 1977 to 2000. Journal of the American Society for Information Science and Technology. 55 (1), 64-73.

Wahyudi, A.; Kustoyo, A.; Sulistyo-Basuki. (2015). Analisis pola produktivitas penulis artikel bidang perpustakaan dan informasi di Indonesia: Suatu kajian bibliometrika. Jurnal Pustakawan Indonesia. 14, (2), 2534. 